\title{
ВПЛИВ ІМУННОЇ КАСТРАЦІЇ СВИНОК НА ЇХНІ ЗАБІЙНІ ТА М'ЯСНІ ЯКОСТІ ЗА РІЗНОЇ ПЕРЕДЗАБІЙНОЇ ЖИВОЇ МАСИ
}

\author{
Андрєєва Діана Миколаївна \\ аспірант спеціальності 204 «ТВППТ » \\ Миколаївський національний аграрний університет \\ ORCID ID: 0000-0003-4572-0856 \\ Email: andreevasvk@gmail.com
}

Повод Микола Григорович доктор сільськогосподарських наук, професор Сумський національний аграрний університет ORCID ID: 0000-0001-9272-9672/ W-1565-2018

Email: nic.pov@ukr.net

\begin{abstract}
В статті порівняно забійні та м'ясні якості імунокастрованих та некастрованих свинок отриманих від помісних свиноматок ірландського ландраса та ірландського йоркшира і кнурів синтетичної лінії Мaxgro забитих за різної передзабійної живої маси. Встановлено, що туші імунокастрованих свинок мали тенденцію до збільшення в них частки маси балику до маси охолодженої туші на 0,44\% за передзабійної маси 110 кг і 0,99\% за забою з масою130 ке, частки балику $i$ ній відповідно на 0,15 і 054\%. Товщина шпику не мала суттєвих розбіжностей в тушах некастрованих та імунокастрованих свинок за передзабійної живої маси 110 ке, тоді як в 130 ке простежувалась тенденція до зменшення на 0,30-1,70 мм або 0,79-3,82\% цих показників в тушах імунокастрованих свинок порівняно з некастрованими. Водночас некастровані свинки мали тенденцію збільшення довжини туші на 0,31\% та ії беконної половинки 1,56\% за передзабійної живої маси 110 ке та на 0,10\% і 2,04 \% за передзабійної маси 130 ке. За рештою показників що вивчались суттевої різниці між групами не встановлено. За допомогою двофракторного дисперсійного аналізу було встановлено що на основні морфометричні показники туш та вихід деяких напівфрабрикатів впливає в більшій мірі передзабійна жива маса, в значно меншій мірі фактор імунокастрації і практично не впливає взаємодія цих факторів. Так вірогідну силу впливу фактору передзабійної живої маси на довжину туші склала 51,12\%; на довжину беконної половинки - 54,63\%, середню товщину шпику за значення трьох промірів - 22,09\%, масу задньої третини напівтуші - 74,45\%, масу балику - 39,79\% та площу «м'язового вічка» на - 20,10\%. Тоді як імунна кастрація свинок вплинула тільки на довжину беконної половинки туші з силою 6,07\% та на масу балику з силою 5,78\% і вірогідно не впливала на інші досліджувані показники. Взаємодія факторів передзабійної живої маси та імунокастрації свинок мала вірогідний вплив тільки на масу балику в туші на рівні 9,46\% і не вплинула на решту досліджуваних показників. Отримані результати досліджень засвідчили, що застосування імунної кастрації для свинок не несе в собі негативного впливу на забійні та м'ясні якості тварин.
\end{abstract}

Ключові слова: свинка, імунна кастрація, забійні показники, м'ясні показники, передзабійна жива маса, маса окосту, площа «м'язового вічка»

DOI: https://doi.org/10.32845/bsnau.Ivst.2020.4.3

Найважливішою особливістю прогресивних технологій виробництва свинини $є$ використання більш цінних генотипів, застосування інноваційних технологій утримання та годівлі свиней, а також підтримання та покращення благополуччя тварин у свинарській галузі. Одним з заходів в даному напрямку $є$ припинення кастрації тварин без анестезії. Так з 31 грудня 2021 - го року десять виробників свиней у Західній Франції планують повністю припинити хірургічну кастрацію поросят, та впровадити використання імунної кастрації [2]. Останнім часом виробники свинини впроваджують імунологічну кастрацію і для свинок з метою підвищення їх продуктивності. Питання використання вакцин для затримки продукування статевих гормонів у свиней та їх вплив на продуктивність і якість м'яса недостатньо вивчені. В попередніх наших публікаціях наведено порівняльну характеристику відгодівельних якостей некастрованих та імунокастрованих свинок. Наступним завданням стало дослідити вплив імунної кастрації свинок на забійні та м'ясні показники туші.

Метою імунокастрації є дезактивація функцій яєчок та яєчників шляхом нейтралізації гормонів гіпоталамогіпофізарно-гонадна вісь. В основному це передбачає вак-

цинацію тварин проти гіпофіз-лютеонізуючого гормону (ЛГ) або гіпоталамічний гонадотропін-рилізинг гормон $(\mathrm{GnRH})$, обидва є ключовими гормонами, які регулюють репродуктивну фуннццію. Вакцинація проти GnRH включає ін'єкцію аналога $\mathrm{GnRH}$, кон'югованого в чужорідний білок і в поєднанні з ад'ювантом для ініціації транзиторного утворення антитіл проти $\mathrm{GnRH}$, які можуть зв'язуватися і пригнічують дію ендогенного $\mathrm{GnRH}$ [7]. Так за повідомленням M. Gispert, та ін.[8] які досліджували вплив імунокастрації кнурців на якість м'яса в туші порівняно 3 м'ясом самок, некастрованих та хірургічно кастрованих самців, встановлено, що застосування імунної кастрації зменшує неприємний запах кнура та інші змінні якості м'яса. Глибина туші в області попереку імунокастрованих кнурців була більше схожа з тушами хірургічно кастрованих кнурців, тоді як в районі шинки вони були більше схожі на туші самок. Туші імунокастрованих самців були більш осаленими, ніж туші некастрованих їх аналогів.

В своїх дослідженнях Yongqiang Хue [10] серед некастрованих, імунокастрованих та хірургічно кастрованих самок свиней породи SuHuai встановили, що концентрація прогестерону в крові свинок яким одноразово вводили вакцину Improvac була значно вищою $(P<0,05)$, порівняно 3 
хірургічно кастрованими свинками та тим яким дворазово та триразово вводили цю вакцину. Середня вага яєчників і матки та частота прояву еструсу самок свиней у з дворазовою та триразовою вакцинацією були значно $(P<0,01)$ нижчими, ніж у тварин з одноразовою, тоді як різниця між свинками з дворазовим та триразовим введенням вакцини не була суттєвою. Суттєвих відмінностей у рості серед чотирьох досліджуваних груп не виявлено, за винятком кращої ( $P<0,05)$ конверсії корму у тварин з дворазовим введенням вакцини. Значних розбіжностей в якості мяса серед піддослідних груп не було встановлено за винятком більш високого вмісту внутрішньом'язового жиру у тварин з одноразовою вакцинацією в порівнянні 3 дворазовою та триразовою (Р $<0,01)$. Це свідчить, що імунокастрація успішно пригнічує розвиток статевих залоз і не має негативних наслідків для продуктивності росту, а також ознак туші або якості м'яса у китайських свиней сухуайської породи. Дослідженнями А. Daza, M. A. Latorre 3 співавторами [3] які вивчали вплив імунокастрації та дієти на основі гранульованого ячменю на показники росту та якість туші, встановлено, що імунокастрація свинок, призначених для виробництва сушеної шинки, покращила деякі аспекти росту та якісні показники туші і м'яса, тоді як гранульований ячмінь мало впливав на продуктивні показники свинок та жирнокислотний склад їх м'яса, але покращував вміст внутрішньом'язового жиру в ньому.

Після затвердження директиви ЄC 2008/120/EC від 18/12/2008 р.[6] в якій зазначені вимоги щодо підвищення добробуту тварин, в тому числі заборона проводити хірургічну кастрацію свиней без анестезії, що стало причиною пошуку альтернативних способів кастрації кнурців. Одним із найефективніших та доступним методом кастрації стало використання імунної кастрації кнурців. Багато зарубіжних вчених $[4,5,7,9]$ провели низку досліджень, щодо застосування імунної кастрації у свинарстві. Та виявили позитивний ефект імунної кастрації за рахунок пригнічення функціонування статевої системи, на відгодівельні, забійні та післязабійні якості свиней. Враховуючи позитивний досвід імунокастрації самців свиней, деякі виробники свинини розпочали її використання для свинок. Вивчення її впливу на продуктивні якості відгодівельних свинок в умовах України є недостатньо вивченим. Тому нами було дослідження ефективності імунної кастрації для свинок в умовах промислового виробництва степу України.

Мета роботи - дослідити характеристику забійних та м'ясних якостей імунокастрованих та некастрованих свинок за різних вагових кондицій.

Матеріали та методи досліджень. Для виконання поставленої мети, нами було проведено експериментальне дослідження на базі ТОВ «НВП «Глобинський свинокомплекс» в цеху відгодівлі №3, у другій половині серпня 2020 року. Матеріалом для дослідження слугували свинки отримані від помісних свиноматок ірландського ландраса та ірландського йоркшира і кнурів синтетичної лінії Maxgro. За методом груп аналогів було сформовано в віці 70 діб дві групи свинок по 220 голів кожна. До І-ї - (контрольної) ввійшли некастровані свинки. До II - (дослідної) ввійшли такі ж свинки, яким у віці 112 днів було введено вакцину Improvac фірми Зоетіс Україна з розрахунку 2 мл на голову, та проведено ревакцинацію цією ж вакциною у віці 148 днів в такій же дозі. Тварини контрольної і дослідної групи були постав- ленні на відгодівлю по 55 голів в сусідніх станках на повністю щілинній підлозі 3 розрахунку $0,75 \mathrm{~m}^{2}$ на одну голову. Через два дні після постановки в приміщення для відгодівлі всі вони були індивідуально зважені, та проідентифіковані за допомогою різнокольорових бирок з індивідуальними номерами. Впродовж всього періоду відгодівлі, який склав 106 діб, свинкам обох груп були створені ідентичні умови годівлі та утримання. Годівля тварин була повнораціонна, збалансована, рідкими мішанками.

По закінченню відгодівлі, свиней, безпосередньо на фермі провели індивідуальне зважування тварин обох груп, на основі якого були сформовані чотири групи по 10 тварин які відрізнялись за масою, а саме:

- I група - некастровані свинки живою вагою 110 кг;

- II група -некастровані свинки живою вагою 130 кг; $110 \mathrm{\kappa г;}$

- III група - імунокастровані свинки живою вагою 130 кг.

- IV група - імунокастровані свинки живою вагою

Всім свинкам перелічених вище груп перед відправкою на м'ясокомбінат провели додаткове мічення за допомогою татуювання на задній третині тулуба, для їх подальшої ідентифікації під час забою та обваловування. Після чого їх завантажили в окремі відсіки спеціального автомобіля і перевезено на Глобинський м'ясокомбінат, де по завершені 24 годинної витримки вони були повторно зважені та відправлені в цех забою. Забій проводили відповідно до ДСТУ 7158:2010 [1]. За результатами забою визначали основні забійні показники свиней відповідно до загальноприйнятих методик. Товщину шпику, в мм на рівні 6-7 грудних хребців, в крижах та в холці визначали за допомогою мірної лінійки. Довжину туші та довжину беконної половинки встановлювали за допомогою мірної стрічки в см.

На наступну добу було проведено зважування охолоджених туш та обвалювання всіх напівтуш піддослідних тварин. В результаті їх розрубу та обваловування було встановлено масу окосту, кг (правого та лівого окремо), масу балику, кг (правого та лівого окремо) та визначено площу «м'язового вічка», см²

Результати досліджень. Згідно отриманих результатів, встановлено незначні відмінності забійних показників між некастрованими та імунокастрованими тваринами вагової категорії 110 кг, більші відхилення спостерігались між некастрованими і імунокастрованими свинками вагової категорії 130 кг на користь некастрованих тварин.

За забійною масою та масою охолодженої туші між тваринами I контрольної та III дослідної групами спостерігалась тенденція до незначного перевищення некастрованих свинок порівняно з імунокастрованими тваринами відповідно на 0,24\% та 0,37\%. Забійний вихід в цих двох групах був на однаковому рівні і становив 76,5\%.

Забійна маса та маса охолодженої туші некастрованих свинок вагової категорії 130 кг була більшою відповідно на 2,40 кг або на 2,49\% та 2,7 кг або на 2,85\% в порівнянні 3 імунокастрованими тваринами цієї ж вагової категорії, що на наш погляд пов'язано з різницею в 2,40 кг передзабійної живої ваги між тваринами II контрольної та IV дослідної групи. За цієї передзабійної маси вищий на 0,3\% забійний вихід мали некастровані свинки порівняно з імунокастрованими аналогами. 
Таблиця 1

Забійні та м'ясні показники некастрованих та імунокастрованих свинок, $(n=10)$

\begin{tabular}{|c|c|c|c|c|}
\hline \multirow{2}{*}{ Показник } & \multicolumn{2}{|c|}{ Контрольна (некастровані свинки) } & \multicolumn{2}{|c|}{ Дослідна (імунокастровані свинки) } \\
\hline & $\mathrm{I}-110 \mathrm{kr}$ & II - $130 \mathrm{k \Gamma}$ & III - $110 \mathrm{kr}$ & IV - $130 \mathrm{kr}$ \\
\hline Середня жива маса перед відправкою на м'ясокомбінат, кг & $113,0 \pm 0,35$ & $132,7 \pm 0,55$ & $113,4 \pm 0,65$ & $133,3 \pm 0,35$ \\
\hline Середня передзабійна жива маса, кг & $107,4 \pm 0,35$ & $125,0 \pm 0,55$ & $107,5 \pm 0,65$ & $122,6 \pm 0,35$ \\
\hline Втрати живої маси під час транспортування та голодної витримки, кг & 5,6 & 7,7 & 5,9 & 10,7 \\
\hline Забійна маса, кг & $82,1 \pm 0,77$ & $96,5 \pm 0,58$ & $82,3 \pm 0,80$ & $94,1 \pm 1,09$ \\
\hline Забійний вихід, \% & 76,5 & 77,2 & 76,5 & 76,8 \\
\hline Середня маса охолодженої туші, кг & $80,5 \pm 0,71$ & $94,8 \pm 0,21$ & $80,2 \pm 0,59$ & $92,1 \pm 0,98$ \\
\hline Втрати при охолоджені, кг & $1,6 \pm 0,21$ & $1,7 \pm 0,21$ & $2,1 \pm 0,36$ & $2,0 \pm 0,20$ \\
\hline Втрати при охолоджені, \% & 1,9 & 1,8 & 2,5 & 2,1 \\
\hline \multicolumn{5}{|l|}{ Товщина шпику, мм: } \\
\hline над 6-7 грудним хребцем & $32,0 \pm 1,69$ & $35,7 \pm 1,39$ & $32,0 \pm 0,92$ & $34,4 \pm 0,86$ \\
\hline в крижах & $29,1 \pm 2,09$ & $33,2 \pm 0,98$ & $28,4 \pm 1,38$ & $32,0 \pm 1,54$ \\
\hline в холці & $42,1 \pm 1,34$ & $44,5 \pm 1,30$ & $42,3 \pm 0,50$ & $46,2 \pm 1,23$ \\
\hline середнє значення трьох промірів & $34,4 \pm 1,59$ & $37,8 \pm 0,99$ & $34,2 \pm 0,78$ & $37,5 \pm 0,87$ \\
\hline Довжина туші, см & $97,3 \pm 0,74$ & $101,8 \pm 0,84$ & $97,0 \pm 0,70$ & $101,7 \pm 0,86$ \\
\hline Довжина беконної половинки, см & $83,5 \pm 0,86$ & $88,4 \pm 0,53$ & $82,2 \pm 0,62$ & $86,6 \pm 0,71$ \\
\hline \multicolumn{5}{|l|}{ Маса окосту, кг: } \\
\hline правого & $13,1 \pm 0,19$ & $15,2 \pm 0,21$ & $13,2 \pm 0,27$ & $15,0 \pm 0,23$ \\
\hline лівого & $13,1 \pm 0,23$ & $15,5 \pm 0,31$ & $13,2 \pm 0,21$ & $15,2 \pm 0,15$ \\
\hline загальна маса & $26,2 \pm 0,42$ & $30,7 \pm 0,52$ & $26,4 \pm 0,48$ & $30,2 \pm 0,38$ \\
\hline Частка окосту до маси охолодженої туші,\% & 32,55 & 32,38 & 32,92 & 32,79 \\
\hline Площа «м'язового вічка», см² & $65,8 \pm 2,49$ & $73,0 \pm 2,07$ & $65,0 \pm 1,98$ & $70,7 \pm 2,42$ \\
\hline \multicolumn{5}{|l|}{ Маса балику, кг: } \\
\hline правого & $3,0 \pm 0,07$ & $3,5 \pm 0,06$ & $3,1 \pm 0,10$ & $3,2 \pm 0,10$ \\
\hline лівого & $2,9 \pm 0,11$ & $3,6 \pm 0,05$ & $2,9 \pm 0,05$ & $3,2 \pm 0,08$ \\
\hline загальна маса & $5,9 \pm 0,18$ & $7,1 \pm 0,11$ & $6,0 \pm 0,15$ & $6,4 \pm 0,18$ \\
\hline Частка балику до маси охолодженої туші,\% & 7,33 & 7,49 & 7,48 & 6,95 \\
\hline
\end{tabular}

Менші втрати маси при охолодженні мали туші некастрованих свинок вагової категорії 110 кг, які склали 1,9 кг, у подібних їм тушах імунокастрованих свинок цей показник склав 2,5 кг.

Товщини шпику на рівні 6-7 грудних хребців, в крижах, в холці та середнє їх значення за передзабійної живої маси 110 кг не мали суттєвих розбіжностей в тушах некастрованих та імунокастрованих свинок, тоді як з підвищенням цієї маси до 130 кг простежувалась тенденція до зменшення на 0,30-1,70 мм або 0,79-3,82\% цих показників в тушах імунокастрованих свинок порівняно з некастрованими.

Некастровані свинки мали тенденцію до більшої довжини туші та її беконної половинки. Так некастровані свинками за передзабійної живої маси 110 кг мали на 0,30 см або 0,31\% довші туші та на 1,30 см, що склало 1,56\% довжину беконної половинки в порівнянні з імунокастрованими. Схожа тенденція за наведеними вище показниками спостерігалась і між тушами некастрованих та імунокастрованих тваринами вагової категорії 130 кг. Так відхилення за показниками довжини туші та довжини беконної половинки склало 0,10 см та 1,80 см або на $0,10 \%$ та на $2,04 \%$ на користь некастрованих свинок.

За масою окосту виявлена протилежна тенденція. Перевага імунокастрованих свинок над некастрованими склала 0,10 кг або 0,76\% за передзабійної живої маси 110 кг та за загальною часткою окосту до маси охолодженої туші 0,44\%. За передзабійної живої маси 130 кг така перевага імунокастрованих тварин над некастрованими склала 0,99
$\%$.

Водночас площа «м'язового вічка» була більшою у некастрованих свинок. Так простежувалась тенденція до збільшення площі «м'язового вічка» у тварин І-ї групи порівняно $з$ III-ю на 0,80 см² або 1,22\% та між свинками II ї та IV ї груп на 2,30 см² або1,88\%.

Не встановлено значної різниці між тушами некастрованих та імунокастрованих свинок різних вагових категорій за масою правого та лівого балику. Але, виявлено меншу частку балику до маси охолодженої туші у некастрованих свинок вагової категорії 110 кг на 0,15\% порівняно з імунокастрованими тваринами такої ж вагової категорії. У свинок вагової категорії 130 кг спостерігається зворотна тенденція, тобто частка балику до маси охолодженої туші некастрованих свинок була більшою на 0,54\% в порівнянні з імунокастрованими аналогами.

Методом двофакторного дисперсійного аналізу визначено силу впливу передзабійної маси та кастрації тварин на їх забійні якості. Так дослідженнями встановлено вплив факторів передзабійної живої маси та кастрації свинок на довжину беконної половинки, виявилися статистично значним ( $F_{\text {передзабійна жива маса }} 50,25>F_{\text {критичне }} 4,11, F_{\text {тип кастрації }} 5,58>$

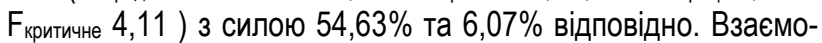
дія цих двох факторів не мала вірогідного впливу на довжину беконної половинки. Невраховані фактори змінювали досліджуваний показник з силою $39,14 \%$ (рис. 1). 


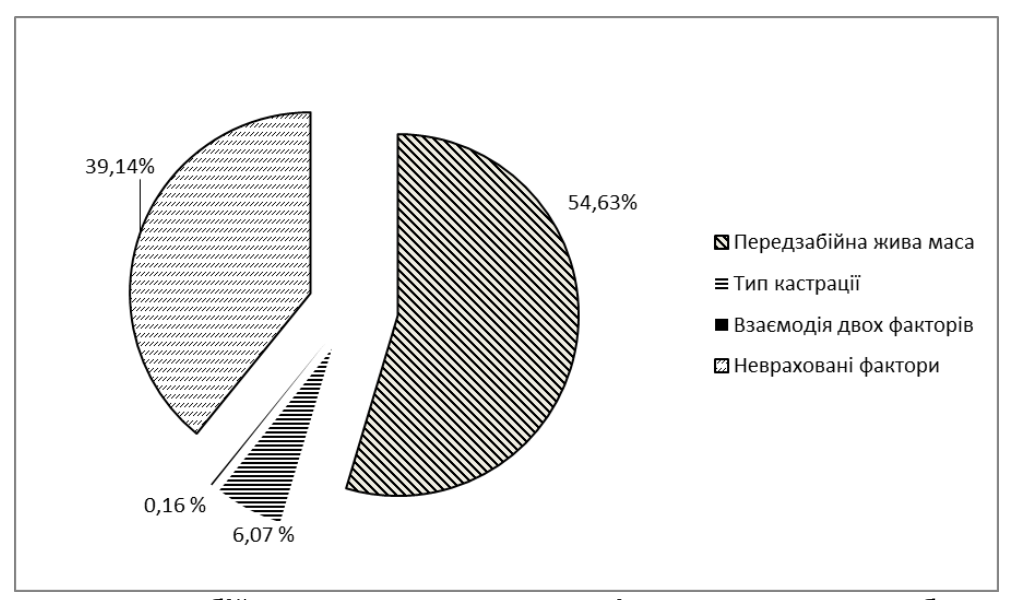

Puc. 1. Сила впливу передзабійної живої маси та кастрації свинок на довжину беконної половинки

Аналіз впливу досліджуваних факторів на зміну показника довжини туші виявив статистично достовірний

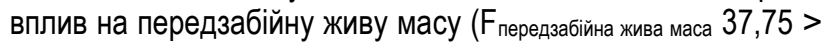
$\left.\mathrm{F}_{\text {критичне }} 4,11\right)$ в межах $51,12 \%$. Статистично не вірогідними виявилися вплив фактору кастрації та його взаємодія 3 передзабійною живою масою на цю ознаку. Невраховані фактори вплинули на зміни показника довжини туші з силою $48,76 \%$ (рис. 2).

Результат впливу передзабійної живої маси свинок на середнє значення товщини шпику були статистично значними ( $\left.F_{\text {передзабійна жива маса }} 10,22>F_{\text {критичне }} 4,11\right)$ в межах 22,09\%, тоді як тип кастрації та фактор взаємодії цих двох фракторів не мали статистично вірогідного впливу на досліджуваний показник. Невраховані фактори змінювали показник товщину шпику з силою $77,82 \%$. (рис. 3 ).

Двофакторним аналізом встановлено достовірний вплив фактору передзабійної живої маси тварин на масу

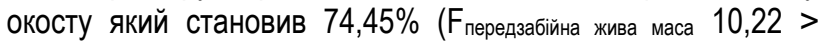
$\left.F_{\text {критичне }} 4,11\right)$ тоді як не виявлено вірогідного впливу факторів типу кастрації і взаємодії факторів передзабійної живої маси та типу кастрації на досліджуваний показник за сили впливу неврахованих факторів на даний показник на рівні $25,05 \%$ (рис. 4).

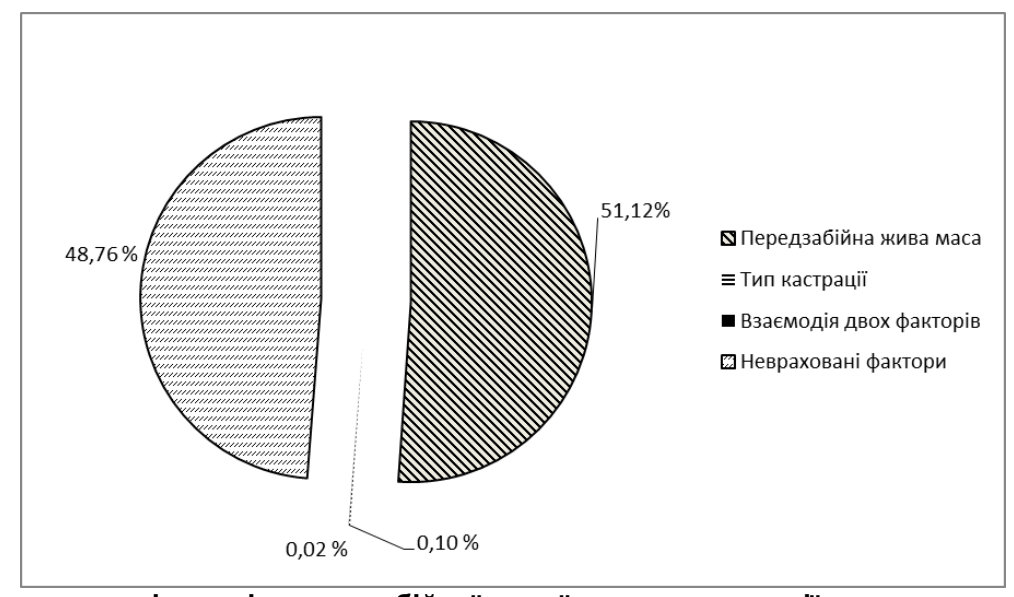

Puc. 2. Сила впливу факторів передзабійної живої маси та кастрації свинок на довжину туші

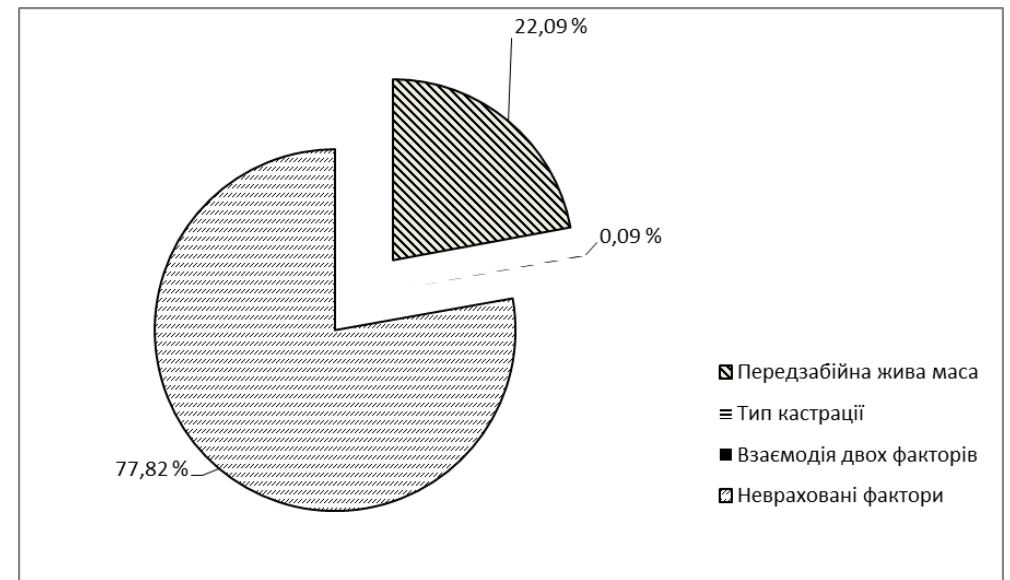

Puc. 3. Сила впливу факторів передзабійної живої маси та кастрації свинок на середнє значення товщини шпику 


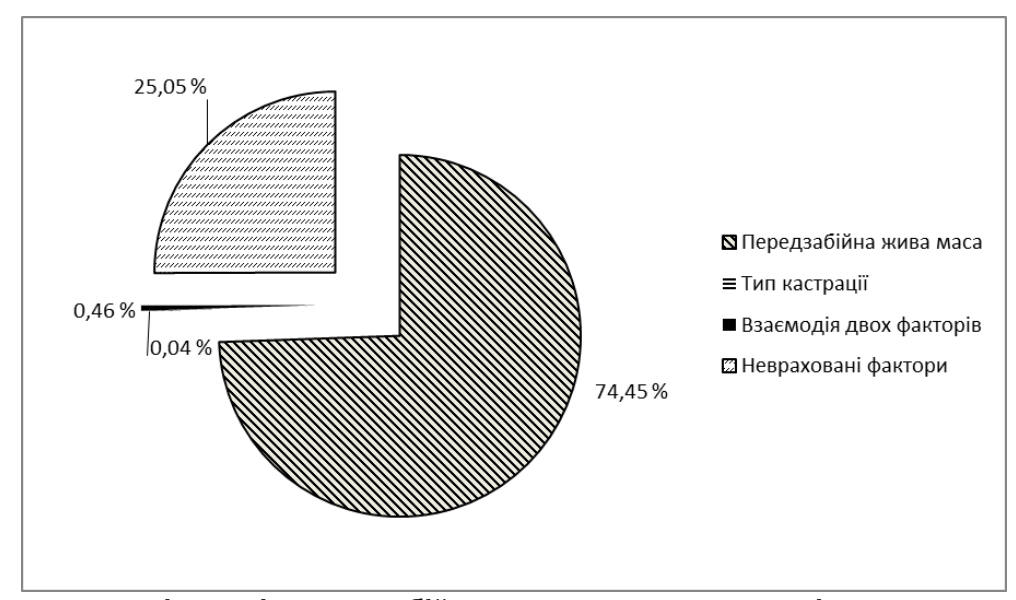

Рuc. 4. Сила впливу факторів передзабійної живої маси та кастрації свинок на масу окосту

Аналіз факторів передзабійної живої маси та кастрації, і їх взаємодії на масу балику встановив їх достовірний

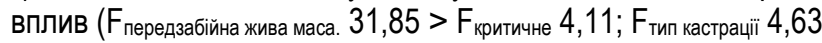

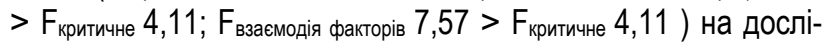

джуваний показник з силою 39,79\%, 5,78\% та 9,46\% відповідно. Невраховані фактори спричинили зміну досліджуваного показника з силою впливу $44,97 \%$ (рис. 5 )

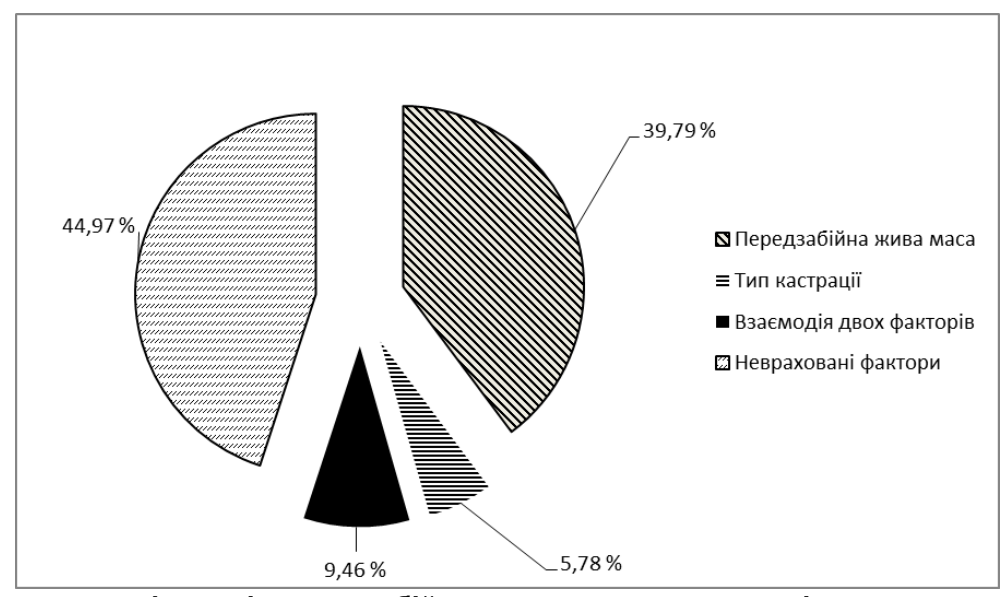

Puc. 5 Сила впливу факторів передзабійної живої маси та кастрації свинок на масу балику

Результати дослідження впливу фрактору передзабійної живої маси на площу «м'язового вічка» виявилися

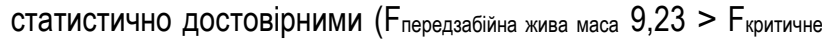
4,11) та змінювали досліджуваний показник з силою 20,10\%. Невраховані фактори мали впливали на показник площі «м'язового вічка» з силою 78,41\%. Фактор кастрації тварин та взаємодія фракторів передзабійної живої маси та кастрації свинок не мали статистично вірогідного впливу на даний показник (рис. 6).

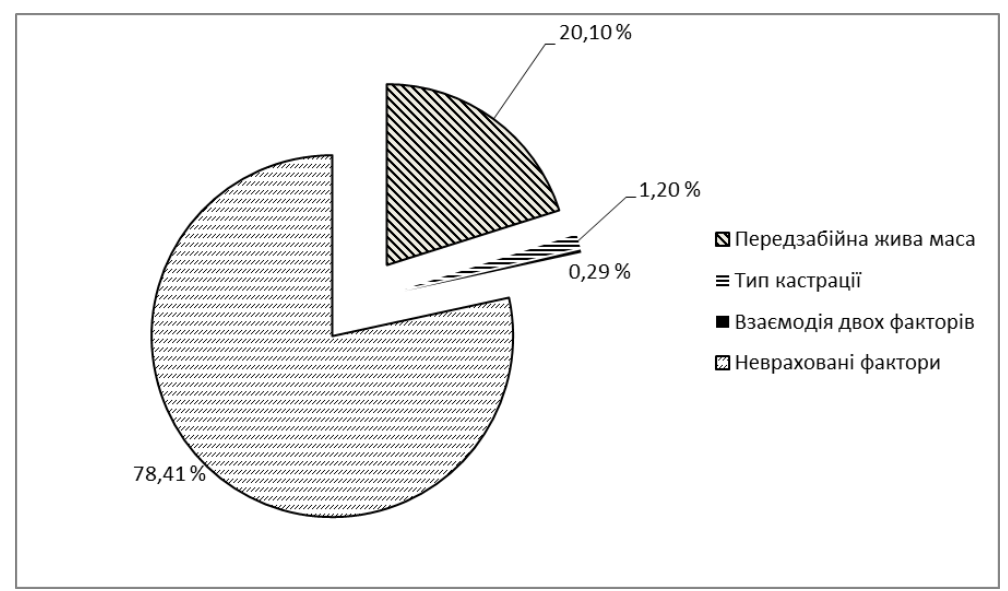

Puc. 6. Сила впливу факторів передзабійної живої маси та кастрації свинок на площу «м'язового вічка»

Таким чином на основні морфометричні показники туш та вихід деяких напівфабрикатів впливає в більшій мірі передзабійна жива маса, в значно меншій мірі фрактор імуно- кастрації і практично не впливає взаємодія цих факторів.

Висновки. 1. За результатами досліджень встановлено, що застосування імунної кастрації для свинок не несе 
у собі негативного впливу на забійні та м'ясні якості тварин.

2. За такими м'ясними якостями як: маса правого та лівого окосту, частка окосту до маси охолодженої туші, маса правого балику, а також частка балику до маси охолодженої туші спостерігалась тенденція до збільшення їх у імунокастрованих тварин порівняно зі своїми некастрованими аналогами.
3. Згідно з результатами двофракторного дисперсійного аналізу забійні та м'ясні показники значним чином залежали від фактору передзабійної живої маси, тоді як дія фактору типу кастрації та взаємодія фракторів вагової категорії та типу кастрації на більшість досліджуваних показників не мала статистично вірогідного впливу.

\section{Список використаної літератури:}

1. М'ясо. Свинина в тушах і півтушах. Технічні умови: ДСТУ 7158:2010. - [Чинний від 2011-01- 01]. - К.: Держспоживстандарт України - 2010. - 11 с.

2. Свинарство в Україні та світі: veb-sait. URL: http://pigua.info/uk/post/francia-dekilka-virobnikiv-planuut-povnistupripiniti-kastraciu-porosat. [Aaccessed 28.12 .2020].

3. A. Daza, M. A. Latorre, A. Olivares and C. J. López-Bote. 2014. The effect of immunocastration and a diet based on granulated barley on growth performance and carcass, meat and fat quality in heavy gilts. Journals animal, Volume 8 , Issue 3, pp. 484 - 493. DOI: https://doi.org/10.1017/S1751731113002292.

4. Batorek N., Čandek-Potokar M., Bonneau M., Van Milgen J.. 2012. Meta-analysis of the effect of immunocastration on production performance, reproductive organs and boar taint compounds in pigs. Published online by Cambridge University Press. The International Journal of Animal Biosciences. 6(8): 1330-8. DOI: 10.1017/S1751731112000146.

5. Čandek-Potokar M., Škrlep M., Zamaratskaia G. Immunocastration as alternative to surgical castration in pigs. In book: Theriogenology publisher: InTech. 6 th. 2017. DOI: 10.5772/intechopen.68650.

6. European Union. Council Directive 2008/120/EC of 18 December 2008 laying down minimum standards for the protection of pigs. OJ L 47, 18.02.2009.

7. Galia Zamaratskaia a Martin Kroyer Rasmussenb. Immunocastration of male pigs - situation today. Procedia food science, volume 5, 2015, pp. 324-327. https://doi.org/10.1016/.profoo.2015.09.064.

8. Marina Gispert, M. Àngels Oliver, Antonio Velarde, Paloma Suarez, Jesús Pérez, Maria Font i Furnols. Carcass and meat quality characteristics of immunocastrated male, surgically castrated male, entire male and female pigs. Meat science 85 , 2010, pp. 664-670

9. Škrlep M., Šegula B., Zajec M, Kastelic M., Košorok S., Fazarinc Čandek - Potokar G.,. Effect of immunocastration (Improvac®) in fattening pigs i: growth performance, reproductive organs and malodorous compo. Slov Vet Res; 47 (2). 2010. pp. 57-64.

10. Yongqiang Xue, Weijiang Zheng, Feng Zhang, Shiting Rao, Zhifeng Peng and Wen Yao. Effect of immunocastration on growth performance, gonadal development and carcass and meat qualityof SuHuai female pigs. Animal production science. 2019. 59. pp.794-800. DOl.org/10.1071/AN16733.

\section{References:}

1. Meat. Pork in carcasses and carcasses. Technical conditions: DSTU 7158: 2010. - [Valid from 2011-01-01]. - Kyiv: Derzhspozhyvstandart Ukrainy - 2010. - 11 p.

2. Pig breeding in Ukraine and the veb-sait. URL: http://pigua.info/uk/post/francia-dekilka-virobnikiv-planuut-povnistu-pripinitikastraciu-porosat. [Aaccessed 28.12 .2020].

3. A. Daza, M. A. Latorre, A. Olivares and C. J. López-Bote. 2014. The effect of immunocastration and a diet based on granulated barley on growth performance and carcass, meat and fat quality in heavy gilts. Journals animal, Volume 8 , Issue 3, pp. 484 - 493. DOI: https://doi.org/10.1017/S1751731113002292.

4. Batorek N., Čandek-Potokar M., Bonneau M., Van Milgen J.. 2012. Meta-analysis of the effect of immunocastration on production performance, reproductive organs and boar taint compounds in pigs. Published online by Cambridge University Press. The International Journal of Animal Biosciences. 6(8): 1330-8. DOI: 10.1017/S1751731112000146.

5. Čandek-Potokar M., Škrlep M., Zamaratskaia G. 2017. Immunocastration as alternative to surgical castration in pigs. In book: Theriogenology publisher: InTech. 6 th. DOI: 10.5772/intechopen.68650.

6. European Union. Council Directive 2008/120/EC of 18 December 2008 laying down minimum standards for the protection of pigs. OJ L 47, 18.02.2009.

7. Galia Zamaratskaia a Martin Kroyer Rasmussenb. 2015. Immunocastration of male pigs - situation today. Procedia food science, volume 5, pp. 324-327. https://doi.org/10.1016/j.profoo.2015.09.064

8. Marina Gispert, M. Àngels Oliver, Antonio Velarde, Paloma Suarez, Jesús Pérez, Maria Font i Furnols. 2010. Carcass and meat quality characteristics of immunocastrated male, surgically castrated male, entire male and female pigs. Meat science 85 , pp. 664-670

9. Škrlep M., Šegula B., Zajec M, Kastelic M., Košorok S., Fazarinc Čandek - Potokar G. 2010. Effect of immunocastration (Improvac $囚$ ) in fattening pigs i: growth performance, reproductive organs and malodorous compo. Slov Vet Res; 47 (2). pp. 57-64.

10.Yongqiang Xue, Weijiang Zheng, Feng Zhang, Shiting Rao, Zhifeng Peng and Wen Yao. 2019. Effect of immunocastration on growth performance, gonadal development and carcass and meat qualityof SuHuai female pigs. Animal production science. 59. pp.794-800. DOI.org/10.1071/AN16733.

Andrieieva Diana Mykolaivna, graduate student special.204 «TVPPLP», Mykolayiv National Agrarian University (Mykolaiv, 
Ukraine) Ukraine)

Povod Mykola Hryhorovych, Doctor of Agricultural Sciences, Professor, Sumy National Agrarian University (Sumy,

Influence of immune castration of pigs on their slaughter and meat qualities at different pre-slaughter live weight

The article compares the slaughter and meat qualities of immunocastrated and uncastrated pigs obtained from local sows of Irish Landrace and Irish Yorkshire and boar of the synthetic line Mahdcho slaughtered at different pre-slaughter live weight. It was found that the carcasses of immunocastrated pigs tended to increase in them the proportion of balyk weight to the weight of chilled carcass by $0,44 \%$ at a pre-slaughter weight of $110 \mathrm{~kg}$ and 0,99\% at slaughter with a mass of $130 \mathrm{~kg}$ of balyk share in it by 0,15 and $0,54 \%$. The thickness of the lard did not have significant differncesy in the carcasses of uncastrated and immunocastrated pigs at pre-slaughter live weight of $110 \mathrm{~kg}$, while in $130 \mathrm{~kg}$ there was a tendency to decrease by $0,30-1,70 \mathrm{~mm}$ or $0,79-3,82 \%$ of these indications in the carcasses of immunocastrated pigs compared to uncastrated. At the same time uncastrated pigs tended to increase the length of the carcass by $0,31 \%$ and its bacon halves by $1,56 \%$ at a pre-slaughter live weight of $110 \mathrm{~kg}$ and by $0,10 \%$ and $2,04 \%$ at a pre-slaughter weight of $130 \mathrm{~kg}$. For the remaining indicators studied, no significant difference between the groups was found. Using two-factor analysis of variance, it was found that the main morphometric parameters of the carcass and the yield of some semi finished products are affected to a greater extent by pre-slaughter live weight to a much lesser extent by immunocastration factor and almost no interaction of these factors. Thus, the probable force of influence of pre-slaughter live weight factors on the length of the carcass was $51,12 \%$ on the length of the bacon half - $54,63 \%$, the average thickness of the lard for the value of three measurements $-22,09 \%$, the weight of the rear third of the carcass $-74,45 \%$, the weight of the balyk - 39,79\% and the area of the eternal muscle by $-20,10 \%$. Whereas immune castration of pigs affected only the length of the bacon half of the carcass with a force of $6,07 \%$ and the weight of the balyk with a force of - 5,78\% and probably didn't affect the other studied indexes. The interaction of factors of pre-slaughter live weight and immunocastration of pigs had a probable effect only on the weight of the balyk in the carcass at the level of 9,46\% and didn't affect the rest of the studied indicators. The results of studies have shown that the use of immune castration for pigs doesn't have a negative impact on slaughter and meat qualities of animals.

Key words: mumpigs, immune castration, slaughter indicators, meat indicators, pre-slaughter live weight, ham mass, muscle eye area.

Дата надходження до редакції: 05.12.2020 р. 